\title{
The association between estrogen receptor alpha gene rs746432 polymorphism and the risk of breast cancer
}

\author{
Bei Wang $^{1}\left[\right.$ D $\cdot$ Fenlai Yuan ${ }^{1}$
}

Received: 12 August 2018 / Accepted: 17 August 2018 / Published online: 21 August 2018

○) Springer Science+Business Media, LLC, part of Springer Nature 2018

\section{Dear Editors,}

With great interests, we have read a recent article entitled "Estrogen receptor alpha haplotypes and breast cancer risk in older Caucasian women," which was published online in Breast Cancer Res Treat [1]. In this article, Wang et al. found that there were no statistically significant associations between rs 746432 polymorphism and the risk of breast cancer.

The article written by Wang stated that genotype distributions of each SNP were analyzed for fitness in HWE except for SNP rs 1801132 in controls. Nevertheless, careful examinations of data reported by Wang et al. reveal a key issue that is worth mentioning. From the data supplied by Wang, we found that the control groups of rs 746432 deviated from HWE $(P<0.05)$, which led to an unconvincing conclusion about the association between rs 746432 polymorphism and the risk of breast cancer.

So far, only few studies were conducted to investigate the relations between rs 746432 polymorphism and the risk of breast cancer. Gallicchio et al. found no significant association between rs 746432 polymorphism and the breast cancer risk in the population-based cohort of women with BBD, while Gold et al. observed that haplotypes containing the SNP rs746432 had an obvious association with the breast cancer $[2,3]$. Generally speaking, the conclusions drawn by Wang should be interpreted with caution. In the future, we need further large-scale and rigorous studies to assess associations between rs746432 polymorphism and the risk of breast cancer.

Funding None.

\section{Compliance with ethical standards}

Conflict of interest All the authors declare no conflict of interest.

Ethical approval This article does not contain any studies with human participants or animals performed by any of the authors.

\section{References}

1. Wang J, Higuchi R, Modugno F, Li J, Umblas N, Lee J, Lui LY, Ziv E, Tice JA, Cummings SR, Rhees B (2007) Estrogen receptor alpha haplotypes and breast cancer risk in older Caucasian women. Breast Cancer Res Treat 106(2):273-280. https://doi. org/10.1007/s10549-007-9497-8

2. Gallicchio L, Berndt SI, McSorley MA, Newschaffer CJ, Thuita LW, Argani P, Hoffman SC, Helzlsouer KJ (2006) Polymorphisms in estrogen-metabolizing and estrogen receptor genes and the risk of developing breast cancer among a cohort of women with benign breast disease. BMC Cancer 6:173. https://doi. org/10.1186/1471-2407-6-173

3. Gold B, Kalush F, Bergeron J, Scott K, Mitra N, Wilson K, Ellis N, Huang H, Chen M, Lippert R, Halldorsson BV, Woodworth B, White T, Clark AG, Parl FF, Broder S, Dean M, Offit K (2004) Estrogen receptor genotypes and haplotypes associated with breast cancer risk. Cancer Res 64(24):8891-8900. https://doi. org/10.1158/0008-5472.CAN-04-1256
Bei Wang

xuewuhenwang@126.com

1 Department of Central Laboratory, Third Hospital Affiliated to Nantong University, Wuxi, Jiangsu 214041, China 